\title{
Foucault, Governmentality, Neoliberalism and Adult Education - Perspective on the Normalization of Social Risks
}

\section{Martin Kopecký}

Abstract: The article deals with the relevance of the work of Foucault to critical analysis of the political concept of lifelong learning that currently dominates. This concept relates to the field of adult education and learning. The article makes reference to the relatively late incorporation of Foucault's work within andragogy. It shows the relevance of Foucault's concept of a subject situated within power relations where the relation between knowledge and power plays a key role. The analysis of changing relations between knowledge and power will help us to understand important features of neoliberal public policies. The motif of human capital is key. The need to continually adapt to the changing economic and social conditions follows on from the neoliberal interpretation of learning, and the individual is to blame for failure on the labour market or in life generally.

Key words: governmentality, neoliberalism, lifelong learning, risks, power, subject

\section{Introduction}

In our attempts to understand the sphere of (adult) education, we cannot avoid the issue of power and social relations. Adult education has long developed away from state power; the state has long perceived it with misgivings or has shown little interest in it [Pöggeler 1990]. It was not until the end of the twentieth century that the situation changed significantly and adult education became part of mainstream education policy - not directly, but as part of the concept of lifelong learning.

Lifelong learning is a very promising project: it foresees great potential in learning and in the necessity of learning as part of the contemporary societal transformations with which it is inseparably connected and which are significantly determined by neoliberal economic globalization. The idea 
that learning is both natural and useful would not generally provoke too many disapproving reactions. However, conflict does exist at a specific level: Which issues can be resolved through lifelong learning? Why is it lifelong learning that provides the solution? And what do we seek to achieve by supporting and coordinating learning?

When critically analyzing these and similar questions, it may be useful to turn to Foucault, the author of one of the most penetrating theories of power. This theory may help us understand how the currently dominant political concept of lifelong learning uses images of individuals and society and how it is used in the management of people as human resources and/or as bearers of human capital (latently as opposed to overtly), and thus contributes to creating the project of modernity.

\section{Foucault as a topical (and complicated) classic}

Over the past two decades the field of andragogy has seen both persistent and increasing attention being paid to Foucault. Two factors, in particular, that are mutually interconnected are responsible for this. The first is rather general, while the second has its origin in current developments in politics and the adult education as it is today. These factors will be introduced in more detail in the sections that follow.

Both educational science and andragogy are characterized by the delay with which they have absorbed the crucial intellectual basis of social theories originating from philosophy and the social sciences. Understandably, pedagogy and andragogy do not number amongst those fields where great diagnoses of modern societies are made, but at the same time these fields need to address such diagnoses. To a large extent, education and learning are social phenomena. This is reflected by the fact that discussions on education always - whether explicitly or implicitly - include a message as to the nature of the society in question (what it is or could or should be). Incidentally, when the word society is used here, it does not necessarily refer to society as a whole; more often, it refers to partial statements about the economy, culture, social relations, or just some of their aspects.

Pedagogy and andragogy generally focus on social theories that have already been elaborated to a certain degree and that have demonstrable worth in expert discussions. This was the case with postmodernism, for example, that had been a subject for debate in philosophy and later on in sociology since the late 1970s, but did not gain attention in pedagogy until as late as the 1990s. With some exaggeration, it may be said that both disciplines tend to accept theories that have already been proven. This feature relates, among other things, to something that could be described as tangibility. 
The field of education is largely reactive by nature. Rather than directly determining the form of societal changes, education is a field which reflects broader social changes. What a philosopher or social scientist diagnoses as an important new finding is not usually the most obvious in the field of education. In a sense, education as a system is conservative in nature. Changes that have already taken place or that can be clearly seen to be taking place in politics and economy, for example, are only gradually starting to find their way into education. ${ }^{1}$

The fact that Foucault's thinking was incorporated into pedagogy and andragogy rather late should not be held against him. The very fact that it has been incorporated demonstrates the significance of his work. If anything, the time delay demonstrates how farsighted Foucault's theses and conclusions were.

The second factor emphasizes what we have just mentioned about the sense of urgency. Foucault was already an extremely influential and highly debated author by the time of his death in 1984. Educational research, however, would first recognize his contribution during the 1990 s. $^{2}$ Interest in Foucault has not diminished and Foucauldian studies have been successfully developed (focusing on a wide range of topics). This is due in no small part to the fact that neoliberalism, with which Foucault was intensely concerned in later life (especially in the years 1977-1979), began to flourish (in terms of political success) only during the 1980s and was further bolstered in the post-Cold War era. ${ }^{3}$ It even declared itself as the winner of the Cold War and strengthened its role as one of the defining features of globalization [Olssen, Peters 2005]. Not even the critical stages of the development of global neoliberal capitalism, including the economic crisis that began in the autumn of 2008, were to bring a great shift away from neoliberal approaches - on the contrary, they strengthened, and in a way, encouraged them. This holds true not only of economic policy, but of other policies as well, including education policy.

In addition to these two reasons for the delay with which Foucault was included in disciplines dealing with education, there is one more factor. And that is the style of the extensive and varied works of the thinker himself. Barša [2005: 87] refers to Foucault's deliberate ambiguity and inconsisten-

1 The time delay, however, does not mean it is immune or resistant to change.

2 It should be added that there were isolated exceptions to this fact [Nicoll, Fejes 2008a: xi]. However, even in 1997, Inglis [1997: 3] considers Foucault's influence on adult education to be slight.

3 It is not too surprising that Foucauldian governmentality studies have their origin in Great Britain. As will be shown later, the current neoliberalism makes Foucauldian analysis perhaps even more relevant than it was at the time of its origin. 
cy. Foucault not only underwent several intellectual shifts, but he typically expressed himself by leaving some of his reflections unfinished and by leaving space for the reader to cope with the presence of white spots or his use of hyperbolic language [Barša 2005: 88]. Thus, there is considerable freedom for different interpretations of Foucault's work.

It is not unreasonable to state that the work of Foucault is classic, comparable to Weber to a certain extent, and perhaps even to Marx, and not only in terms of the extent of his influence on the direction of social sciences. Foucault and Weber not only share the fact that they conducted simultaneous work in several disciplines (philosophy, sociology, history, law, etc.) but they are also linked through their problematisation of the idea of freedom in modern society while abandoning the attempt to comprehensively capture social and cultural resources applicable in the defence against the loss of freedom [Honneth 1997: xxvii]. Similarities between Foucault and Marx may at least be found in the way they divided their intellectual work into several stages ${ }^{4}$, their focus on the problem of power and the presence of a paradox, which is only a seeming paradox. Neither Marx nor Foucault devised a comprehensive theory of education. Marx is concerned only marginally with education in the "Communist Manifesto" or in the "Theses on Feuerbach"; Foucault mentions school in Discipline and Punish [2000a] and analyses education in the context of the theory on human capital in his lectures on biopolitics [2009]. However, the work of both authors offers exceptionally inspiring statements on modern society and the people living within it with regard to areas which are closely related to education or that significantly determine its nature. Among them, the issue of social relations and their interconnection with power and freedom stands out.

The Critical Theory of the Frankfurt School can be introduced here as an imperfect (and certainly debatable) link connecting Marx, Weber and Foucault. Shortly before his death, in one of his interviews, Foucault [2000b: 53] expressed regret over the fact that he had not come across the Frankfurt School ${ }^{5}$ during his studies, nor even long after he had finished them. "Now, obviously, if I had been familiar with the Frankfurt School, if I had been aware of it at the time, I would have avoided many of the detours which I made while trying to pursue my own humble path - when meanwhile, avenues had been opened up by the Frankfurt School. It is a strange case of non-penetration between two very similar types of thinking which is ex-

\footnotetext{
4 The controversy over the continuity or discontinuity of these stages in both thinkers is avoided here.

5 Foucault was obviously referring to its first generation.
} 
plained, perhaps, by that very similarity. Nothing hides the fact of a problem in common better than two similar way of approaching it".

The thing that brings Foucault and the Frankfurt School together is their interest in the development and role of rationality (inspired by Nietzsche), as well as their use of a multidisciplinary approach (especially philosophy, sociology and psychology). Both perspectives deal with the proposition that diagnosing modern society is impossible without analysing human thinking, especially the kind of thinking that has its roots in the Enlightenment. In order to successfully identify the origin and contradictions of how people think, it is necessary to reveal the fact that although entities act relatively freely, they are not their own masters because (and that is not the only reason) they do not control the conditions in which they act. There are a variety of forms of rationality. In the predominant one, we do not realize its pitfalls. Furthermore, it is the case that correcting the unfavourable consequences caused by dominantly practiced forms of thinking and acting would not come from rationality itself. ${ }^{6}$

To be precise, it is necessary to add a reference to the partial closeness of Foucault and neomarxism generally, including Gramsci [see Kaščák and Pupala 2010: 776]. I mention this because the practice of modern adult education was developed significantly in the nineteenth century and partly the twentieth century within various social movements, particularly the labour social movement [Olesen 1996]. The role played by (neo)Marxism in adult education is also crucial in terms of normativity [Finger, Asún 2001] and its influence may be compared with philosophical pragmatism and humanistic psychology.

In this context it is worth mentioning a book edited by Nicoll and Fejes [2008] that deals with the applicability of Foucault's work to the policy and practice of adult education today which is perceived as a part of lifelong learning. One of the contributors, Gert Biesta, in his retrospective, provides an overview of the approaches of other authors who addressed the question "so what?" in various ways in relation to Foucault. The first group of authors simply concerned themselves with diagnosis and criticism, and did not offer any recommendations for practice. The second group (unintentionally, rather than intentionally) linked the Foucauldian approach with the traditional view of emancipation. It was only the third group that dealt with a Foucauldian concept of analysis that excludes the possibility of treating power as a tool for reform, and yet does not abandon the issue of action.

6 All these statements may be hard to understand now, but I believe that what follows will succeed in clarifying them - especially the second and third sections of this article. 


\section{Basic elements of Foucauldian analysis}

It is now appropriate to, at least very briefly, present the broader context of Foucault's work, in which his concept of governmentality is set. Therefore, I will briefly discuss the relationship between a subject, power, and freedom and the issue of normality.

It is difficult to precisely locate power; it is generally present in (all) social relations and discourses. ${ }^{7}$ It is not directly owned by anyone (not even by the state). Power is not transferred as property and it must be examined as an apparatus [Foucault 2000a: 179]. Power relations are changeable [Foucault 2003]. The exercise of power is related to all participants, including those who are generally referred to as powerless - they too help to create power relations through their way of thinking and their actions. We are both influenced by power and deal with it at the same time. The concept of power definitely cannot be identified with the concepts of violence and oppression. Power, subject and freedom are much closer to each other than we are usually able to perceive. It is through the subject and subjectification that power is practised; a subject separated from other subjects constitutes a sort of bridge between freedom and power. In other words, freedom and power are not mutually exclusive but mutually dependent. "Hence, government is not opposed to Freedom, but operates through freedom." [Simons and Masschelein 2008: 54]. Although it may still sound paradoxical, it becomes more compelling if we add that freedom and various constraints are not mutually exclusive [Olssen 2010]. A subject becomes a subject as well as an object [Foucault 2003: 195]. Freedom is always practiced under certain conditions - and these are not determined by the subject. Freedom thus operates as if invisibly governing; the subject is both active and governed [Fejes 2008]. "To govern, in this sense, is to structure the possible field of action of others" [Foucault 2003: 217]. "The individual is no doubt the fictitious atom of an 'ideological' representation of society; but he is also reality fabricated by this specific technology of power that I have called 'discipline'. We must cease once and for all to describe the effects of power in negative terms: it 'excludes', it 'represses', it 'censors', it 'abstracts', it 'masks', it 'conceals'. In fact, power produces; it produces reality; it produces domains of objects and ritual truth. The individual and the knowledge that may be gained of him belongs to this production" [Foucault 2000a: 195].

7 Therefore, it is possible to talk about an emphasis on the microphysics (microtechnology) of power in Foucault's work.

8

Olssen [2010: 63] considers Foucault to be an author who has something to say about any society and, in analyzing totalitarian power, he may have more to offer than Popper, for example. 
Other important items in Foucault's vocabulary, besides discipline, include terms such as observation, examination and normalization. They all occur in his description of modern education, but, in no way does education have a monopoly over them; they are basically inherent to all modern organizations and power relations. For example, modern medical science sets standards that distinguished the normal from the abnormal. Realizing the form and mechanism of pathologizing may, for example, lead us to question modern psychiatry and the emergence of the anti-psychiatric movement. The same applies to medical science and homosexuality. Foucault also provides us with the conclusion that normalization is not normal (natural) and must be problematized, although the path to that is neither straight nor easy. The influence of normalization is possible precisely because it works by appearing to be neutral (caused, for example, by specialist jargon or by referring to the "neutral" truth, facts and common sense).

In modern society, normality is associated with performance and with the fact that it is possible to guarantee one's performance and its predictability. The subject as well as the context with which the subject is associated is dependent on the connection between knowledge and power. Here, it is appropriate to mention the concept of governmentality (the compound word itself suggests much). "This contact between the technologies of domination of others and those of the self I call governmentality" [Foucault 2000c: 188]. The concept of governmentality does not concern violence, fight or right, but only governing [Foucault 2003: 217; 2000d: 153].

As Nicoll and Fejes [2008b: 11-13] put it, the concept of governmentality is elaborated in two directions. The first focuses on the practices of governing. Various forms of power in society are examined, emphasizing bio-power in particular. Bio-power governs the population as a production resource which should be used and optimized (in schools, etc.). ${ }^{9}$ The second concerns governmentality and concentrates on "governing through the freedom and capacities of the individual and this requires and forms a particular and technical 'mentality' within liberal democratic states" [Nicoll, Fejes 2008b: 11-12].

Within the concept of governance as self-governance, people identify with the requirement of self-optimization. The needs of organizations are connected (or even identified) with the needs of individuals. Du Gay [according to Edwards 2008: 28] talks about "enterprising of the self". Governmentality assumes that everything may be governed, all that is required is mastery of the appropriate techniques, such as self-management, stress management, time management, etc. [Usher, Bryant, Johnston 1997: 58].

9 Bio-power is further applied in health care, social and demographic policies. 


\section{Neoliberal concept of lifelong learning - origins and ensuing social practices and risks}

It is possible to determine numerous reasons why Foucault may have analysed neoliberalism and the concept of human capital, and why there should be Foucauldian analyses and a neoliberal concept of education. The connection between power and knowledge can be seen in each discourse and the regime of truth it creates, even though the discourse pretends to aim at the truth and there is no element of power contained therein [Usher, Bryant, Johnston 1997: 81]. This is particularly interesting in cases where discourse is frequently shielded by conservatism but at the same time pursues radical changes to the status quo. In this regard, neoliberalism is remarkable. It places great emphasis not only on the economization of education, but it also considers education to be a mechanism for separating able students from less able ones. Thanks to education, those who are able manage to adapt to the requirements of the environment and thus profit from it. We are thus facing a strongly individualized version of the concept of meritocracy oriented towards competition. ${ }^{10}$

The emphasis on the connection between economic logics and various sections of social life as well as the life of the individual comes from American neoliberalism, which originated at the Chicago School of Economics. American neoliberalism must be understood as being far more complex than just an economic or political choice [Foucault 2009: 192]. Its interest in considering and reconstructing the entire society according to economic criteria is in a way anthropological. According to neoliberalism, man is an autonomous and competitive being, whose behaviour is guided by the principles of cost and revenue calculation. There are no significant exceptions to this rule, which is both natural and best of all the known imperatives. Radical neoliberals relate this rule to matrimony, the upbringing of children, health issues, criminality, etc. The more economic freedom there is, the more human freedom there is.

The most prominent authors of the Chicago school, for instance G. S. Becker [1993], had by the end of the twentieth century presented education as an efficient investment increasing economic welfare. A successful future may be secured by means of education as a way of developing human capital. The individual's prospects on the labour market as well as on other markets are determined by the amount of capital that individual holds. Investment in education represents postponed consumption; it is an investment

10 The basic features of human capital theory as applied to education were metaphorically summarized by Baptiste [2001] in his study entitled "Educating Lone Wolves: Pedagogical Implications of Human Capital Theory". 
with reliable revenue, which forms the basis of the competitive ability of individuals as well as entire countries. That is why it is legitimate to push, for instance, for the introduction of tuition fees at universities.

In a way, the act of conveying upon each individual the role of bearer of human capital and the entrepreneur of this capital establishes a logic whereby various spheres of human life are put in an economic context. Thus, there is a need to see the individual as part of a labour force that should bring profit to real companies [Keller 2011: 69].

In the history of scientific thought, it would be hard to find another theory which has captured so much interest in the field of politics as the theory of human capital. A certain analogy could perhaps be found in the case of social capital. The latter concept is the "twin" or rather a younger sibling of the former. The human capital discourse has not won such wide acclaim due to its accuracy; it suffers from too many weak spots for that. ${ }^{11}$ Its success consists in the fact that many influential political (and economic) organizations use the concept. OECD, which has in recent years been decisive in formulating educational policies, is perhaps the most important one.

OECD is the author of what is currently (since the mid-1990s) the most influential political concept of lifelong learning ${ }^{12}$ [Rubenson 2004; 2009]. This discourse stems from the concept of human and social capital already mentioned $^{13}$ as well as from other concepts - especially the ideas concerning a knowledge society and knowledge economy. The "capitalist" logic is also characteristic for this discourse [Jarvis 2007; Jacobi 2007].

Expert opinion and political discussions relating to human capital, the knowledge society and lifelong learning ought to be linked to other contemporary discussions determined by the neoliberal logic - on the role of science, schools, universities as well as on the changes to social policy. ${ }^{14} \mathrm{Nev}$ ertheless, the following paragraphs shall touch on only two issues related to adult education. I will first focus on the image of the adult learner as found, both expressly and implicitly, in the current political discourses. Secondly,

11 Rubenson [2008] draws attention to the rise in social inequality caused by an imbalance in education and in the impossibility of finding adequate jobs for all higher education graduates.

12 Apart from OECD, the World Bank, EU and UNESCO have also formulated their concepts of lifelong learning. These differ from each other, with the World Bank displaying the strongest tendency towards neoliberalism; where the EU is concerned, it is somewhat weaker. The approach of UNESCO is the least economizing and at the same time it stresses the issues of developing democracy and solving social problems [Rubenson 2009].

13 In this respect, the output of OECD [2001; 2007] is enormous compared to many others.

14 See Foucault [2009]. 
I shall concentrate on the present forms of managing people in organizations that frequently refer to learning. I shall follow the basis for the normalization of social risks developed with the contribution of these two fields.

Lifelong learning is a concept which has been part of mainstream global economic and political vocabulary since the 1990s [Jarvis 2007]. At first sight, it seems to be a promising (or rather promise-making) programme; it mentions supporting learning opportunities throughout the individual's life and making use of the advantages it offers [Rasmussen 2009]. Lifelong learning has become the central axis not only for the field of education but also in social and economic politics [Martin 2003]. This concept is a more recent version, albeit rather disconnected, of the older notion of lifelong education. The differences between the two concepts go far beyond the "innocent word" of learning. Learning refers to the individual and his or her own responsibility for the course and the outcome of learning [Jarvis 2007: 6466] and thus for his or her total ability to achieve success (to prevent failure). The moral duty to learn is derived from the discourse in which learning is presented, that is, as a powerful tool of individual success. Learning has thus been altered so that it is a rule; it becomes an obligation. We can therefore talk of responsibilisation. We can thus follow the rise of a new stage of individualization, to which educational policy also contributes. The previous stage consisted in the extension of education after World War II which brought about a new level of in choice of profession as well as new opportunities to manage and think through one's own life as an individual project [Honneth 2007].

Individualization is encouraged by both the educational system and the labour market. Paradoxically, the consequence is that this strengthens the dependency of individuals on precisely these institutions, education and the labour market. In the individualization era there is a noticeable retreat from the political perception of the social difficulties that people encounter (a consequence of this is an increased interest in psychology and various forms of therapy). The loss of opportunities to become a political participant reinforces new social risks [Beck 2003]. In fact, the way to respond to these is to strengthen the mechanisms that cause them (privatization, deregulation, etc).

The prevailing political concept of learning also means that various forms of economic and social problems and individual difficulties are seen not as problems of the system, but as the results of individual failures. Crowther [2004] refers to this as blaming the victim. ${ }^{15}$ The de-politicization of economic and social reform is accompanied by a re-politicization of individu-

15 That means that in practice, for example, marginalized groups are accused of being an economic burden to society. 
als [Pascual 2007: 229]. The need for responsibility is aimed first of all at disadvantaged groups. With a grain of salt, it is therefore possible to draw an analogy between the present and the Enlightenment (Campe) in terms of the latter's requirement that the "unreasonable masses" be disciplined through a schooling that would teach rational earning behaviour [Plumpe 2007].

Nowadays, lifelong learning is ascribed more influence than it really has, especially if it is expected to largely replace the function of the welfare state $^{16}$. The previous sentence does not apply without limitations. Lifelong learning is expected to make a positive contribution to economic growth, innovation and competitiveness or social coherence, but at the level of the individual, these certainties are transformed into (mere) opportunities. An example of this can be seen in the term employability - learning does not provide jobs, but it is meant to increase the chances of finding them. A good life is unthinkable without learning, and the purpose of learning is to adapt to changing conditions. The concept of lifelong learning is frequently used in the construction of a self-optimizing entrepreneurial self [Morgan-Klein, Osborne 2007: 6].

The prevailing concept of lifelong learning is aimed at work [Rubenson 2008]. This may be evidenced by the fact that EU documents, for instance, mention the knowledge economy more often than they mention the knowledge society. Whenever the word economy appears, it refers to performance. Whenever society is mentioned, attention is focused on marginalized groups [Brine 2007: 174]. Instead of a universal emphasis on knowledge, knowledge related to instrumental action - techné - is preferred [Gustavsson 2002]. This, however, does not prevent lifelong learning being presented as support for the development of a knowledge society in the most recent EU documents; just as in the recent past lifelong learning was understood to be one of the creators of such a society [Nicoll, Fejes 2011].

The notion of paradox seems to be most adequate in characterizing the present state. On the one hand there has been an increase in the opportunities to make use of freedom, yet at the same time, there is a need for greater discipline [Honneth 2007: 9]. This also applies to current views on the nature of work and management of people in organizations. Human resources management has turned to the area of knowledge, which it seeks to understand systematically. The capitalism of today has "discovered" that the meaning of knowledge is held in it being a factor in production. With this in mind, it also manages using methods of management that take advantage

16 Attempts to push for more social equality may be considered vain, since equality of opportunity is guaranteed by the universal opportunity to learn. 
of the widest scope of human knowledge in as systematic a manner as possible. If knowledge is capital, it deserves to be managed in the most efficient way; hence, the boom in writing on knowledge management in organizations [Jarvis 2007].

In the writing on management of recent decades, the subject of a learning organization has become almost de rigeur; it is thus older than the concept of knowledge management, which follows up the concept of learning organization. If we disregard the difficulties concerning the very presumption that entire organizations (and not just the people within them) can learn, these ideas (from Argyris and Schön to Senge) are remarkable in that they omit to consider learning within the context of the power relations that exist within the organizations [Jarvis 2007]. The concepts of learning organizations do not automatically take into account issues of power and conflict, but they count on the presence of a natural balanced state. It may be deduced from both these remarks that it is the purpose of managed learning in organizations to help the enterprise to succeed on the market. The individual, as part of the organization, is not seen as being the goal, but rather the means [Jarvis 2007]. The objectives of learning in the learning organization are defined by the management [Casey 2003: 624].

The departure from Fordism and the suppression of employee initiative occurs at other levels as well. Instead of there being a straightforward hierarchy and commands, the tasks of the day are decentralising enterprises, implementing internal marketization and developing the ability to self-manage. Competition has become part of the internal life of the organization, affecting individual departments as well as individuals. Never-ending observations and evaluations have become the mechanism of control. Mechanisms such as databases, appraisals, annual reviews, report writing, applying for promotion, inspections and peer review have all been put to use [Ball $2004]^{17}$. Accountability has become the word of the day. Management takes place not only as a requirement of performance, but also through a desire for performance. External ratings, a mixture of feelings and desires - pride, guilt and envy, etc. - all play their role [Ball 2004].

Management theory has come to understand the individual as a complex personality in the sense that components of personality previously understood as being strictly private (experience, social relations, and competencies) are now subject to development and management. This is referred to as soft human resource management, and its tools include competence management, personal development plans, and 360 degree feedback. Today's

17 This author was one of the first to apply the work of Foucault to educational research [Nicoll, Fejes 2008a]. 
management is presented as empowerment ${ }^{18}$, sensitive to individual and collective cultural differences [Glastra, Schedler, Hake 2000: 161].

The rhetoric of freedom contradicts the inevitable requirement that individuals attempt to be competitive [Keller 2011]; success in competitions is conditioned by conformity.

At this point, we may recall Foucault's point [2000a: 183-191; 2003: 204] which originally related to school and government. Testing combines the techniques of hierarchy and sanction. It strengthens the power of the norm and refers to individual responsibility and homogenization. The relation between individualization and totalization is one of tension and interconnectedness, and both processes deepen over time in modern society [Foucault 2000e: 228].

The existence of self-control mechanisms to be used by the victims of social risks is an important feature of current social risks. The most effective form of social control is self-control itself. "...there is no more effective form of hegemonic social control that is achieved by way of learning that is selfmotivated, self-regulated and self-policed" [Griffin 1999: 449].

At the end of this section we eventually arrive at a question which appears automatically: How is it possible that certain concepts of lifelong learning and management may be so successfully pushed for on a universal scale? Instead of a full-scale analysis, we shall have to be satisfied with a brief and disputable remark. The effectiveness of indirect pressure ${ }^{19}$ stems from having the power to introduce a discourse that includes success as its criteria and evaluation as its tool. Systematic analysis, which superficially appears to be expert analysis, produces a multitude of empirical data and evaluations [Rubenson 2008]. Apart from defining what is mainstream, it can also measure who is included in the mainstream and to what extent. This is the basis of the "freedom" to adapt or to move towards the periphery. This applies to individuals as well as countries.

18 Empowerment, when related to human development, is a very tricky word. On one hand, it is connected with the tradition of radical approaches to adult education (including Freire), and on the other hand, it is one of the terms to be found in management terminology. In the latter case, it refers to freedom of performance in an environment which cannot be influenced freely. It may thus be considered as one of the softer modes of surveillance [Inglis 1997] and finally as a broadening of the modes of control applied [Welton 2005]. "Surveillance becomes ever more pervasive and intrusive yet without appearing to be oppressive." [Usher, Bryant, Johnston 1997: 78].

19 For example, OECD lacks the political power to impose a certain concept of educational policy on states against their will. 


\section{Conclusion}

The intellectual world of neoliberalism is not very sophisticated. It is the serious consequences of the application of neoliberal policies what provokes a polemic. Therefore, it is necessary and even tempting to analyse neoliberal discourse, think it through and come to conclusions about its inherent theses, uncover its hidden levels, conflicts and manipulative thoughts as well as to show the negative impacts of putting it into practice.

It is only at a time when neoliberal policies have been incorporated into policy-making that adult education, being a part of the political concept of lifelong learning, has been integrated into power relations and has co-constituted societies where freedom is confronted with control, inequalities and risks. This is where the need to re-think where the motive for the free individual and the paths available to him or her comes from - for instance, through adult education and learning. Foucault provides a number of catalysts for all that. Neoliberalism may thus be viewed as the final development of governmentality [Keller 2011: 68-69].

\section{References}

Ball, S. J. 2004. Performativities and Fabrications in the Education Economy. In Ball, S. J. (Ed.). The Routledgefalmer Reader in Sociology of Education. London and New York: Routledgefalmer, 143-155.

Baptiste, I. 2001. Educating Lone Wolves: Pedagogical Implications of Human Capital Theory. In Adult Education Quarterly, 51 (3): 184-201.

Barša, P. 2005. Nietzschovské Osvícenství [Nietzschean Enlightenment]. In Barša, P., Fulka, J. Michel Foucault. Politika a estetika. [Michel Foucault. Politics and Aesthetics]. Praha: Dokořán.

Beck, U., Beck-Gernsheim, E. 2003. Individualisation: Institucionalised Individualism and Its Social and Political Consequences. $1^{\text {st }}$ Ed. London: Sage.

Becker, G. S. 1993. Human Capital. A Theoretical and Empirical Analysis, With Special Reference To Education. Chicago and London: The University of Chicago Press.

Biesta, G. 2008. Encountering Foucault in Lifelong Learning. In Fejes, A., Nicoll, K. (Eds.). Foucault and Lifelong Learning. Governing the Subject. London and New York: Routledge, 193-205.

Brine, J. 2007. The European Lifelong Learner. In Kuhn, M. (Ed.). Who is the European? - A New Global Player? Frankfurt Am Main: Petr Lang, 161-178.

Casey, C. 2003. The Learning Workerm Organizations and Democracy. In International Journal of Lifelong Education, 22 (6): 620-634.

Crowther, J. 2004. 'In and Againts' Lifelong Learning: Flexibility and the Corrosion of Character. In International Journal of Lifelong Education, 23 (2): 125-136. 
Edwards, R. 2008. Actively Seeking Subjects? In Fejes, A., Nicoll, K. (Eds.). Foucault and Lifelong Learning. Governing the Subject. London and New York: Routledge, 21-33.

Fejes, A. 2008. Active Democratic Citizenship and Lifelong Learning. A Governmentality Analysis. In Bron, M. Jr, Guimarães, P., Castro, R. V. (Eds.). The State, Civil Society and the Citizen. Exploring Relationships In the Field of Adult Education In Europe. Frankfurt Am Main: Petr Lang, 79-95.

Finger, M., Asún, J. M. 2001. Adult Education at the Crossroads. Learning Our Way Out. London and New York: Zed Books and Leicester: NIACE.

Foucault, M. 2000a. Dozerat' a trestat. Zrod väzenia. [Discipline and Punish. The Birth of the Prison]. Bratislava: Kalligram.

Foucault, M. 2000b. Štrukturalismus a postštrukturalismus. [Stucturalism and Posstructuralism]. In Foucault, M. Moc, Subjekt A Sexualita. Články A Rozhovory. [Power, Subject and Sexuality. Articles and Interviews]. Bratislava: Kalligram, 44-72.

Foucault, M. 2000c. Technológie seba samého. [Technologies of the Self]. In Foucault, M. Moc, Subjekt a sexualita. Články a rozhovory. [Power, Subject and Sexuality. Articles and Interviews]. Bratislava: Kalligram, 186-214.

Foucault, M. 2000d. Etika starostlivosti o seba samého ako prax slobody. [The Ethics of the Concern of the Self as A Practice of Freedom]. In Foucault, M. Moc, subjekt a sexualita. Články a rozhovory. [Power, Subject and Sexuality. Articles and Interviews]. Bratislava: Kalligram, 132-154.

Foucault, M. 2000e. Politická technológia indivíduí. [The Political Technologies of Individuals]. In Foucault, M. Moc, subjekt a sexualita. Články a rozhovory. [Power, Subject and Sexuality. Articles and Interviews]. Bratislava: Kalligram, 215-229.

Foucault, M. 2003. Subjekt a moc. [The Subject and Power]. In Foucault, M. Myšleni vnějšku. [Though of the Outside]. Praha: Herrmann \& Synové, 35-70.

Foucault, M. 2009. Zrozeni biopolitiky. [The Birth of Biopolitics]. Brno: CDK

Glastra, J., Schedler, P. E., Hake B. J. 2000. Transitional Learning In the Information Society. In Hake, B., Van Gent, Katus, J. (Eds.). Adult Education and Globalisation: Past and Present. Frankfurt Am Main: Petr Lang, 153-176.

Griffin, C. 1999. Lifelong Learning and Welfare Reform. In International Journal of Lifelong Education, 18 (6): 431-452.

Gustavsson, B. 2002. What Do We Mean By Lifelong Learning and Knowledge? In International Journal of Lifelong Education, 21 (1): 13-23.

Honneth, A. 1997. The Critique of Power. Reflective Stages in a Critical Social Theory. Cambridge: MIT Press.

Honneth, A. 2007. Organizovaná seberalizace. Paradoxy individualizace. [Organized Self-Fulfilment. Paradoxes of Individualization]. In Honneth, A. (Ed.). Zbavovat se svépráunosti. Paradoxy současného kapitalismu. [Giving Up Independence. Paradoxes of the Present Capitalism]. Praha: Filosofia, 176-196.

Inglis, T. 1997. Empowerment and Emancipation. In Adult Education Quarterly, 48 (1): 3-17. 
Jacobi, A. P. 2007. The Knowledge Society and Global Dynamics in Education Politics. In European Educational Research Journal, 6 (1): 39-51.

Jarvis, P. 2007. Lifelong Learning and the Learning Society: Volume 2. Globalisation, Lifelong Learning and the Learning Society. Sociological Perspectives. London and New York: Routledge.

Kaščák, O., Pupala, B. 2010. Neoliberálna guvernmentalita v sociálnom projektovaní vzdelávania. [Neoliberal Governmentality In Social Designing of Education]. In Sociologický časopis [Czech Sociological Review], 46 (5): 771-799.

Keller, J. 2011. Nová sociální rizika a proč se jim nevyhneme. [New Social Risks and Why We Will Not Avoid Them] Praha: Sociologické Nakladatelství.

Martin, I. 2003. Adult Education, Lifelong Learning and Citizenship: Some ifs and Buts. In International Journal of Lifelong Education, 22 (6): 566-579.

Morgan-Klein, B., Osborne, M. 2007. Lifelong Learning. The Concepts and Practices. London and New York: Routledge.

Nicoll, K., Fejes, A. 2008a. Preface. In Fejes, A., Nicoll, K. (Eds.). Foucault and Lifelong Learning. Governing the Subject. London and New York: Routledge, Ix-Xiv.

Nicoll, K., Fejes, A. 2008b. Mobilizing Foucault in Studies of Lifelong Learning. In Fejes, A., Nicoll, K. (Eds.). Foucault and Lifelong Learning. Governing the Subject. London and New York: Routledge, 1-18.

Nicoll, K., Fejes, A. 2011. Lifelong Learng: A Pacification of 'Know How'. In Studies in Philosophy and Education: First published on 20 March 2011 (Online First) DOI: 10.1007/s11217-011-9235-x.

OECD. 2001. The Well-beeing of Nations. The Role of Human and Social Capital. Education and Skills. Paris: OECD.

OECD. 2007. Human Capital. How What You Know Shapes Your Life. Paris: OECD.

Olesen, H. S. 1996. Adult Education and Everyday Life. Roskilde: Adult Education Research Group. Roskilde University Centre.

Olssen, M., Peters, M. A. 2005. Neoliberalism, Higher Education and the Knowledge Economy: From the Free Market to Knowledge Capitalism. In Journal of Education Policy, 20 (3): 313-345.

Olssen, M. 2010. Liberalism, Neoliberalism, Social Democracy. Thin Communitarian Perspectives on Political Philosophy and Education. London and New York: Routledge.

Pascual, A. S. 2007. Supranational Expertocracy and the Policies of Production of Identities. In Kuhn, M. (ed.). Who is the European? - A New Global Player? Frankfurt am Main: Petr Lang, 227-248.

Plumpe, W. 2007. Racionalita a riziko: k historické povaze moderního hospodár̆ství. [Racionality and Risk: On the Historical Nature of Modern Economy]. In Honneth, A. (ed.). Zbavovat se svéprávnosti. Paradoxy současného kapitalismu. [Giving Up Independence. Paradoxes of the Present Capitalism]. Praha: Filosofia, 15-40.

Pöggeler, F. (ed.). 1990. The State and Adult Education. Frankfurt am Main: Petr Lang. 
Rasmussen, P. 2009. Lifelong Learning as Social Need and as Policy Discourse. In Dale, R.,

Robertson, S. (eds.). Globalisation \& Europeanisation in Education. Oxford: Symposium Books, 85-99.

Rubenson, K. 2004. Lifelong Learning: A Critical Assessment of the Political Project. In Graduate School in Lifelong Learning. Shaping an Emerging Reality - Researching Lifelong Learning. Roskilde: Roskilde University and Roskilde University Press, 28-48.

Rubenson, K. 2008. OECD Education Policies and World Hegemony. In Mahon, R., McBride, S. (eds.). The OECD and Transnational Governance. Vancouver: UBC Press, 242-259.

Rubenson, K. 2009. Lifelong Learning: Between Humanism and Global Capitalism. In Jarvis, P. (ed.). The Routledge International Handbook of Lifelong Learning. London and New York: Routledge, 411-422.

Simons, M., Masschelein, J. 2008. Our Will to Learn and the Assemblage of a Learning Apparatus. In Fejes, A., Nicoll, K. (eds.). Foucault and Lifelong Learning. Governing the Subject. London and New York: Routledge, 48-60.

Usher, R., Bryant, I., Johnston, R. 1997. Adult Education and the Postmodern Challenge. Learning Beyond the Limits. London and New York: Routledge Falmer.

Welton, M. 2005. Designing the Just Learning Society. A Critical Inquiry. Leicester: NIACE.

\section{Author:}

Martin Kopecký, Ph.D., Assistant Professor

Charles University in Prague

Faculty of Arts

Department of Adult Education and Personnel Management

Náměstí Jana Palacha 2

11638 Praha 1

Czech Republic

Email: martin.kopecky@ff.cuni.cz 